\title{
CROP INSURANCE WITH SUBSIDIES IN POLAND - DO IT WORKS?
}

\author{
Aleksandra Wicka ${ }^{1}$ \\ ${ }^{1}$ Faculty of Economic Sciences, Warsaw University of Life Sciences - SGGW, Poland
}

\begin{abstract}
Farming is a risky business. Every farmer has to cope with various kinds of natural, technological, personnel- and market-related risks. The most important strategies in risk management in farming include diversification of production and income, entering into contracts, vertical integration and insurance. Production insurance allows for transfer of risk outside individual farms, allowing them to stabilize their income. Since 2006, insurance is obligatory in Poland for crops and is partially subsidized by the state. Popularization of insurance is still lower than assumed in the programmes devised to provide support for agriculture. The aim of this study is to assess the functioning of compulsory crop insurance subsidized by the state budget in Poland and the reasons limiting its development. The analysed period included years 2006-2016, and for quantitative data - years 2009-2015. The author used statistical data from Central Statistical Office and governmental institutions. It was found that compulsory crop insurance developed dynamically in the early years after introduction of the concept. Each year, about PLN 200 million was paid by the state budget to subsidize crop insurance (ca. EUR 50 million). After year 2010, the area of crops insured reached 3 million hectares and it stopped to increase despite the incentives. Farmers were most eager to secure those crops, which are susceptible to natural risks, as well as those with high shares in the sowing structure. Rapeseed production was insured almost entirely, production of sugar beets and corn - in about $30 \%$, and cereals - in $20 \%$. The most significant barriers preventing popularization of crop insurance in Poland included: fragmentation of farms and low workforce productivity, low income in farming, high diversification of production and income of farms, high significance of direct subsidies in agricultural income, as well as high policy prices and low compensation amounts. In addition, for insurance companies, crop insurance was not profitable. The planned increase in the level of insurance subsidies to PLN 1.4 billion, increase in the level of subsidies to $65 \%$ and the maximum level of subsidized premium to $9 \%$ should contribute to elimination of the barriers observed and achievement of the planned level of crop insurance of $70 \%$ of the area by year 2025 .
\end{abstract}

Key words: risk in agriculture, agricultural insurance, subsidized crop insurance, risk mitigation strategies, crop insurance constraints.

JEL code: Q14, Q18, G22

\section{Introduction}

In every kind of human activity, the risk factor must be taken into account, as it can never be fully eliminated. Risk is also a significant component of farming activity. Uncertainty is associated with the weather, crops, prices, government policy, situation on the global markets and other factors, which may lead to fluctuations in the level of farm income. Risk management is about selection among various alternatives to mitigate the negative financial effect, associated with such uncertainty.

In agricultural production, there are many various risks. The key five risks include:

- production risk,

- price- or market-related risk,

- financial risk,

- institutional risk,

- human or personal risk.

Farmers may undertake various actions to manage the risks encountered; most apply not one, but many different risk management tools. Some of these are associated with a single type of risk; others provide protection against several types (O'Donoghue, 2016; OECD, 2011).

The most popular risk management strategies in farming include (O'Donoghue, 2016, Wicka, 2014): 
- diversification of production and sources of income,

- taking advantage of external financing sources,

- vertical integration in supply chains through takeover of ownership or shares,

- entering into contracts for sale of production and purchase of means of production,

- use of futures or options contracts,

- maintaining of liquid property,

- crop insurance against crop deterioration or natural disasters,

- employment outside the farm to increase the family income.

Agricultural production is subject to many risks. Only some of these can be mitigated by farmers independently, for instance, through diversification of production (Pietrzykowski and Wicki, 2011) or use of varieties characterized by diversified stress resistance (Wicki, 2010). Many farmers take advantage of crop insurance to mitigate risks and reduce income fluctuation. Willingness to insure crops depends on many factors. First of all, it is the observed variability of yields or crop losses (Sulewski and Kloczko-Gajewska, 2014). It has also been indicated that farmers achieving high income and having substantial assets are less eager to get insurance, keeping the risk at their farms (Farrin et al., 2016). Those farmers, who have accumulated substantial property thanks to savings, are able to take advantage of self-insurance even in the case of significant crop losses.

Not all farmers susceptible to risk decide to get insurance. Those, who do, indicate to insurance companies that risks associated with their farms is unobservable. According to Makki and Somwaru (2001), such is the case both when farmers purchase insurance and when the insurance amounts are diversified or only some crops are insured.

In Poland, like in many other countries, insurance was first introduced as a possibility, and later on became an obligation. The programme is subsidized. It was commenced in 2006; however, it has not achieved the planned effect, that is, mitigation of fluctuations in farming income due to risk factors thanks to commercial insurance. A substantial part of the risk is still borne by the state, which supports farmers suffering from crop loss or reduction (Wicka 2014). This is due to the still significant role of farming in Polish economy, particularly in employment (Wicki and Wicka, 2016). However, only 3 million hectares of crops are insured, while the governmental programme assumed about 6 million hectares; without support of the government, popularization of crop insurance is not possible, as the farmers would not be able to pay $100 \%$ of the premiums (Bujoczek, 2017).

Crop insurance is an important component of risk management in agricultural production in Poland. The aim is to provide farmers with financial resources to cover losses in the case of crop loss or reduction due to weather risks. Thus, the market of crop insurance is very much dependent on weather anomalies, which have become increasingly frequent (Bujoczek 2017). In the last decade, they have also led to substantial losses in agriculture in Poland. Such phenomena as substantial snowfall in the late spring, frost in the period of blossoming of fruit trees, strong winds and heavy rains have led to destruction of large crop areas (TopAgrar, 2015, Top Agrar, 2017, Luczak, 2017). An effective agricultural production insurance system should be aimed at maintaining financial and organizational stability of the participating farms (Golebiewska and Golebiewski, 2013; Klimkowski and Rembisz 2014). 


\section{The present situation on the market of crop insurance in Poland}

Crop insurance with premiums subsidized by the state budget has been present in Poland since 2006. Since then, the rules of insurance have been changed many times (Janowicz-Lomott and Lyskawa, 2016). Modifications applied to provisions with regard to the subject and scope of insurance, the level of subsidies from the state budget and definitions of different risks (Milewska and Wicka, 2011). A motivation for the state action in this regard was willingness to popularize insurance among farmers as the method of managing risk at farms. The last change with regard to compulsory crop insurance took place in year 2017.

In 2006, in $27 \mathrm{EU}$ Member States about $23 \%$ of the crop value were insured. Insurance amounted to euro 1583 million, i.e. about $4 \%$ of the declared value of yield. Spain, considered the country with most developed insurance systems in agriculture, in the world, accounts for euro 564 million, with only 5.86 million hectares being insured, indicating a relatively low market penetration ( $26 \%$ of the area). Market penetration in Germany is much higher (7.26 million hectares, i.e. $43 \%$ of crop area), while the average amount of premiums is only euro 129 million. This can be explained by the fact that in Germany insurance usually covers only one risk (hail) (Clipici, Frant, 2013). The total amount of the subsidies to insurance premiums was 497 million euros, representing $32 \%$ of the sum insured. Level of subsidies varies greatly from country to country. In the EU, the highest subsidies to agricultural insurance were registered in Italy and Portugal. In Italy, it was $80 \%$ of sum insured. In other countries, such as the UK, the subsidy is not applied at all. In average sum of compensation paid by insurance companies for a specified year compared to the total amount of contributions from the same period - was in the range of 60 to $70 \%$ (Agricultural Insurance Schemes, 2008).

In Poland, agricultural crop insurance is subsidized by the state on the basis of the act of July 7th, 2005 on the insurance of crops and farm animals. Until year 2015, state subsidies to the insurance premium amounted to $50 \%$. Starting from year 2016, as much as $65 \%$ of the premium has been subsidized. A prerequisite for receiving a subsidy is that the agricultural producer enters into an insurance agreement for 10 risks and the premium being not higher than $9 \%$ of the insurance amount. In the case of cultivation of soil of the poorest quality (class 5 and 6), the tariff rate can be specified as $12 \%$ and $15 \%$ of the insurance amount, respectively. In the case of insurance rates exceeding $9 \%, 12 \%$ and $15 \%$ of the total crop insurance amount, respectively, subsidies to these rates are to be reduced proportionally to the percentage of their increase, excluding tariff rates for the risk of drought and negative consequences of wintering (MRiRW, 2018).

Each farmer can take advantage of subsidized insurance for production of: cereals, corn, rape, hops, tobacco, field vegetables, fruit trees and bushes, strawberries, potatoes, sugar beets and leguminous plants. Risks subject to insurance include hurricane, flood, heavy rainstorm, hail, lightning, landslide, avalanche, drought, negative consequences of wintering and spring frost.

In Poland, only a few insurance companies are interested in sale of subsidized crop insurance. Such insurance is offered by only five out of more than thirty companies, offering property insurance. In 2018, these are the following companies:

1. Powszechny Zaklad Ubezpieczen S.A. with a registered office in Warsaw,

2. Towarzystwo Ubezpieczen Wzajemnych "TUW" with a registered office in Warsaw,

3. Concordia Polska Towarzystwo Ubezpieczen Wzajemnych with a registered office in Poznan, 
4. Pocztowe Towarzystwo Ubezpieczen Wzajemnych with a registered office in Warsaw,

5. InterRisk Towarzystwo Ubezpieczen SA Vienna Insurance Group with a registered office in Warsaw.

The subsidized crop insurance system, developed in Poland, is based on a public-private partnership, which is aimed at aligning of interests of both parties. The aim of the partnership is to allow the public authorities to meet their obligations towards the society - in this case, by securing farms, which, among other things, are responsible for Poland's food security (Janowicz-Lomott and Lyskawa, 2011).

\section{Aim and methods}

The aim of this study is to assess the functioning of compulsory crop insurance subsidized by the state budget in Poland and the reasons limiting its development. Three research tasks have been completed: 1) determination of the level of use of the amount designated to crop insurance subsidy and area of crop subject to insurance compared to the planned use of these insurances, 2) determination of areas of use of crop insurance according to plant species, 3 ) indication of the most significant limitations to development of crop insurance.

The study was based on statistical data from the Central Statistical Office on crop area in Poland and insured crop area. Data concerning insurance subsidies was obtained from reports of the Ministry of Finance and the Ministry of Agriculture and Rural Development. The author also used results of studies, presented in scientific publications.

The analysis includes the period of 2006-2016; however, detailed data on insured crop area is available only for years 2009-2015.

Due to the structure of data and the relatively short data time series, the study was based on structure and dynamics indicators; application of statistical methods was not justified.

\section{Amounts of crop insurance subsidies}

Since year 2006, when subsidies to crop insurance premiums were applied for the first time, the amount in the state budget designated for subsidizing crop insurance has increased systematically. In 2006, it amounted to PLN 55 million; in 2018 - PLN 853 million (Fig. 1).

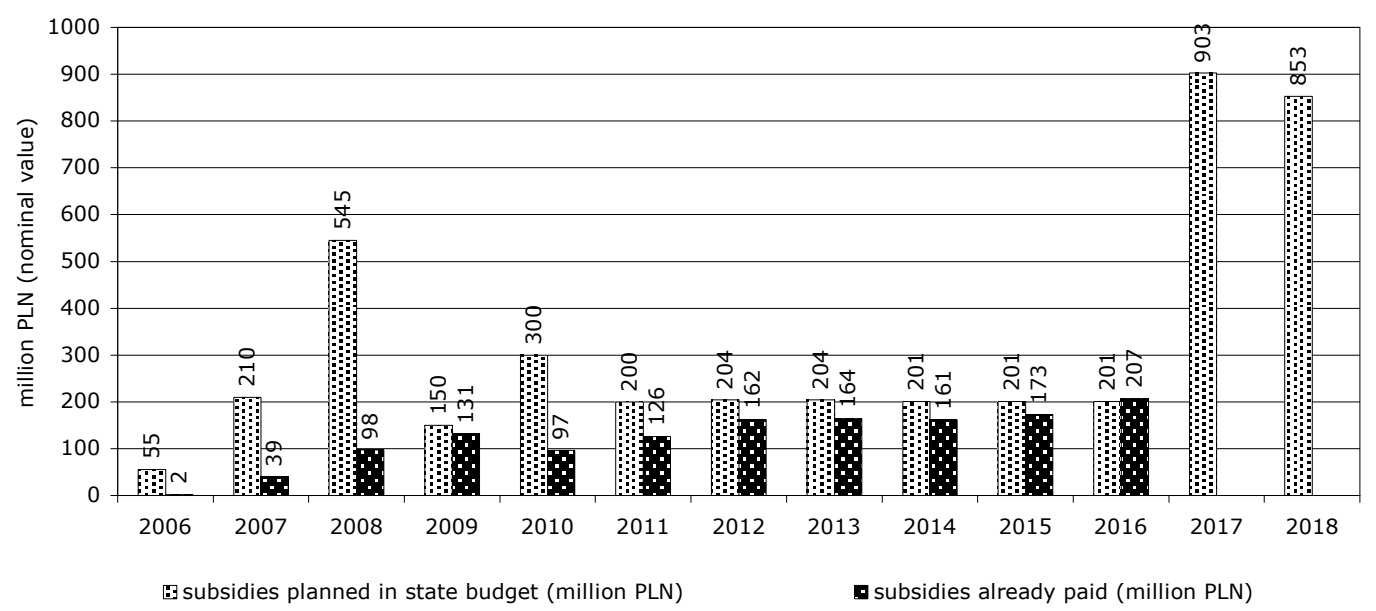

Source: author's own work based on data of the Ministry of Finance for years 2006-2018

Fig. 1. Subsidies for crop insurance planned and paid out in the state budget in years 2006-2018 
In years 2020-2026, insurance subsidies are to increase further to the amount of PLN 1420 million yearly (Janowicz-Lomott and Lyskawa, 2016). This seems justified, taking into account the fact that use of funds has increased from $19 \%$ in year 2007 to $100 \%$ in year 2016. In year 2016, for the first time, the amount designated for subsidizing of insurance premiums was exhausted, and some of the farmers were unable to take advantage of such insurance (Luczak, 2016; Nie podnosic dotacji..., 2016; Tornado w ubezpieczeniach rolnych, 2016; Ubezpieczenia beda..., 2017, Bedzie wiecej pieniedzy..., 2016; Kolejki po polisy, 2016).

\section{Area subject to subsidized crop insurance}

According to legal provisions, the crop insurance obligation is applicable to $50 \%$ of the area of crops subsidized directly on behalf of the farmer. Plant species subject to protection have been listed above. Every farmer, who fails to meet the insurance obligation, is subject to a minor financial penalty, if lack of insurance is detected. Despite the financial sanctions, crop insurance has not been applied to a satisfactory extent. In Poland, the sowing area is about 11 million hectares; thus, about 5.5 million hectares should be insured. In years 2009-2015, insurance was purchased for about 3 million hectares. More detailed characteristics of crop insurance have been presented in Table 1.

Subsidized crop insurance in Poland in years 2009-2015

Table 1

\begin{tabular}{|c|c|c|c|c|c|c|c|}
\hline \multirow{2}{*}{ Item } & \multicolumn{7}{|c|}{ Subsidized crop insurance in Poland in year } \\
\hline & 2009 & 2010 & 2011 & 2012 & 2013 & 2014 & 2015 \\
\hline Area of insured crops (million ha) & 2.81 & 2.85 & 3.03 & 2.75 & 3.40 & 3.27 & 2.82 \\
\hline Insurance contracts (pcs) & $\begin{array}{l}144 \\
080\end{array}$ & $\begin{array}{l}134 \\
986\end{array}$ & $\begin{array}{l}138 \\
425\end{array}$ & $\begin{array}{l}135 \\
707\end{array}$ & $\begin{array}{l}151 \\
101\end{array}$ & $\begin{array}{l}142 \\
492 \\
\end{array}$ & $\begin{array}{l}139 \\
108\end{array}$ \\
\hline The value of insurance (million PLN) & - & 7844 & 10238 & 12087 & 14232 & 13327 & 13695 \\
\hline $\begin{array}{l}\text { Average insurance sum } \\
\text { (PLN per contract) }\end{array}$ & - & 58108 & 73965 & 89068 & 94190 & 93528 & 98449 \\
\hline Average insured area (ha per contract) & 19 & 19 & 22 & 20 & 23 & 23 & 20 \\
\hline Sown area in Poland (million ha) & 11.6 & 10.4 & 10.6 & 10.4 & 10.3 & 10.4 & 10.7 \\
\hline $\begin{array}{l}\text { Share of the insured area in sown area } \\
(\%)\end{array}$ & 24.2 & 27.3 & 28.7 & 26.4 & 33.1 & 31.4 & 26.3 \\
\hline
\end{tabular}

"-" - no data available;

Source: author's own work based on Statistical Yearbook of Agriculture: CSO for years 2010-2016

Some fluctuations have been observed in terms of the share of insured crop area in total sowing area, ranging between $26 \%$ and $33 \%$. However, a growth trend, which was expected to emerge as a result of subsidizing of the insurance premium, has not been observed. 
Structure of area of crops insured under subsidized crop insurance scheme

Table 2 in years 2009-2015

\begin{tabular}{|l|c|c|c|c|c|c|c|}
\hline \multirow{2}{*}{\multicolumn{1}{|c}{ Group of crops }} & \multicolumn{7}{c|}{ Insured area in percent } \\
\cline { 2 - 8 } & $\mathbf{2 0 0 9}$ & $\mathbf{2 0 1 0}$ & $\mathbf{2 0 1 1}$ & $\mathbf{2 0 1 2}$ & $\mathbf{2 0 1 3}$ & $\mathbf{2 0 1 4}$ & $\mathbf{2 0 1 5}$ \\
\hline Cereals & 59.71 & 59.66 & 55.76 & 58 & 56.56 & 53.25 & 55.54 \\
\hline Potatoes & 2.27 & 0.55 & 0.52 & 0.5 & 0.42 & 0.77 & 0.60 \\
\hline Sugar beets & 1.03 & 1.45 & 1.61 & 2.6 & 1.37 & 1.84 & 1.73 \\
\hline Rape & 31.55 & 29.13 & 32.84 & 27.4 & 31.08 & 30.49 & 27.90 \\
\hline Maize & 3.93 & 7.04 & 5.74 & 9.1 & 8.12 & 11.12 & 10.62 \\
\hline Legume crops & 0.59 & 1.08 & 0.66 & 1.04 & 0.63 & 1.04 & 2.22 \\
\hline $\begin{array}{l}\text { Fruit from berry } \\
\text { plantations and fruit } \\
\text { trees }\end{array}$ & 0.49 & 0.27 & 1.75 & 0.25 & 0.23 & 0.30 & 0.46 \\
\hline Field vegetables & 0.29 & 0.38 & 0.87 & 0.66 & 0.36 & 0.56 & 0.56 \\
\hline Total & $\mathbf{1 0 0 . 0 0}$ & $\mathbf{1 0 0 . 0 0}$ & $\mathbf{1 0 0 . 0 0}$ & $\mathbf{1 0 0 . 0 0}$ & $\mathbf{1 0 0 . 0 0}$ & $\mathbf{1 0 0 . 0 0}$ & $\mathbf{1 0 0 . 0 0}$ \\
\hline
\end{tabular}

Source: author's own work based on Statistical Yearbook of Agriculture: CSO for years 2010-2016

In years 2010-2015, the structure of insured crop area was dominated by cereals (Table 2), like the sowing structure. Every year, it exceeded $53 \%$ of insured area. A high share in the insured crop area was also recorded for rapeseed, at the level of $30 \%$ of the total insured crop area. Farmers also showed increased interest in insuring corn - the share of this crop in the total insured crop area increased from $7.0 \%$ in 2010 to $10.6 \%$ in 2016 . Studies on this area indicate that farmers most often insured the crop species, for which insurance premiums were the lowest. This means they don't believe insurance protection to be effective and do their best to meet their obligations while minimizing the associated costs.

Share of crops insured under subsidized crop insurance scheme by groups

Table 3 in years 2009-2015

\begin{tabular}{|l|c|c|c|c|c|c|c|}
\hline \multirow{2}{*}{ Species } & \multicolumn{6}{|c|}{ Share of insured area in total production area in percent } \\
\cline { 2 - 9 } & $\mathbf{2 0 0 9}$ & $\mathbf{2 0 1 0}$ & $\mathbf{2 0 1 1}$ & $\mathbf{2 0 1 2}$ & $\mathbf{2 0 1 3}$ & $\mathbf{2 0 1 4}$ & $\mathbf{2 0 1 5}$ \\
\hline Grains & 19.5 & 23.6 & 22.9 & 20.7 & 25.7 & 23.3 & 20.9 \\
\hline Rapeseed* & 109.4 & 87.6 & 120.0 & 104.8 & 114.7 & 104.9 & 83.2 \\
\hline Maize (grain and silage) & 15.9 & 27.5 & 22.9 & 23.7 & 25.7 & 29.9 & 24.5 \\
\hline Potato & 12.6 & 3.9 & 3.9 & 3.8 & 4.2 & 9.1 & 5.8 \\
\hline Sugar beet & 14.4 & 20.1 & 23.9 & 34.1 & 24.0 & 30.5 & 27.2 \\
\hline
\end{tabular}

* - production area as in June, insured area according to insurance contracts

Source: author's own work based on Statistical Yearbook of Agriculture: CSO for years 2010-2016

In the examined period, rapeseed was encompassed with the broadest scope of insurance. Taking into account winter losses, it can be stated that almost $100 \%$ of rapeseed crops were insured. It should be noted that the insured area applies to sowed area, and sowing area data is recorded at the end of June. On the average, ca. $10 \%$ of rapeseed sowing area is liquidated due to winter damages (Hecka and Lyskawa, 2013). As for other important groups of plants (cereals, grain maize, silage maize, potatoes, sugar beets), the share of insured area was 20 to $30 \%$ (Table 3). A relatively constant share of insured area for key crops was observed; only for maize, there was a substantial increase at the level of more than $5 \%$ annually and for beets it was almost $10 \%$ annually. It can be seen that crops with high income are more willingly insured. These are crops grown on a large scale on the farm and on better soils. Farmers who have small farms or poor soils are less interested in such insurance. For the same reason, farmers who produce livestock and produce mainly feed have little need to insure crops. 


\section{Barriers and chances for development of crop insurance in Poland}

In Poland, it was assumed that crop insurance would be popularized within 2 to 3 years from its introduction. Despite subsidizing of $50 \%$ of the premium, no more than $30 \%$ crops were insured in the subsequent years, although the expected level was at least $50 \%$. The most important identified barriers preventing popularization of crop insurance include: high share of small farms, characterized by low level of sales (Golebiewska, 2011), low share of plant products in production sold, high share of farms specializing in animal production or characterized by a diversified production profile, low workforce productivity (Golebiewski, 2013; Wicki, 2012). In addition, a low level of changeability of farming income was observed, which was due to high share of direct subsidies related to CAP in total income (Hecka and Lyskawa, 2013; Wicka, 2014). Farmers also pointed to the fact that insurance was too expensive for them, while the compensation received was too low to cover the losses suffered (Plonka, 2017; Kaczala, 2015).

From the point of view of insurance companies, the value of compensation paid for losses was high and crop insurance was not profitable for them despite the warranted subsidies (Janc, 2016). After year 2010, crop insurance generated no profit for insurance companies. Therefore, neither farmers nor insurance companies were interested in developing the scope of insurance.

From the perspective of the state, the high number of damages due to extreme weather conditions leading to losses in agricultural production results in the necessity of providing non-insured farmers with support, paid directly from the state budget. This has resulted in the decision to provide additional subsidies for insurance. In order to increase profitability of insurance for farmers, the level of insurance premium subsidies was increased from $50 \%$ to $65 \%$. Insurance companies are to have a warranty of minimum profitability of such insurance, as the acceptable premium level has been increased from $5 \%$ to $9 \%$ of the insurance total - that is, it has been almost doubled. At the same time, a fourfold increase in crop insurance subsidies has been warranted from ca. PLN 200 million to more than 800 million. In the coming years - until year 2026 - these are to reach even PLN 1.4 billion. It is expected that $70 \%$ of crop area in Poland will be insured. Taking into account the situation observed in the field of crop insurance in Poland, it can be concluded that stagnation has occurred in the last 10 years, despite government support. The share of insured crops reached only $30 \%$. The planned increase in the amount of subsidies, increasing the share of subsidies in the insurance premium and increasing the upper limit of the insurance premium, should lead to an increase in the share of the insured area to $60-70 \%$ in the next 5 years. In such development of crop insurance in Poland, the most important obstacles identified are the following: low compensation in relation to incurred damages, rare occurrence of losses exceeding $25 \%$, high share of subsidies in income in small and medium farms, which constitute the majority in Polish agriculture.

\section{Conclusions}

The analysis conducted leads to the following conclusions.

1) Crop insurance may be perceived as an important tool in coping with effects of risk associated with plant production. Since 2006, Poland has implemented the programme of obligatory subsidized crop insurance. The programme was to encompass about $50 \%$ of total sowing area in Poland; so far, the level reached has been $30 \%$. The farmers were primarily interested in the insurance of cash crops, such as rape or sugar beets. Cereals or potatoes were insured in only a small percentage. 
2) In the following years of the program's operation, less funds were used for subsidies to crop insurance than planned in the state budget. This was usually 50 to $80 \%$.

3) The most significant barriers, preventing popularization of crop insurance, include its insignificant impact on the level of income of farmers. This is mainly due to small farming areas, diversified production and sales, stabilization of income as a result of transfers within the framework of CAP. Other limitations include high premium costs and difficulty in claiming damages. Insurance will not attract the attention of small farms, with low income from agricultural production.

4) Increase in the premium subsidy by $30 \%$, increase in the premium value by $50 \%$, as well as increase in the subsidy amount from PLN 200 to 850 million may lead to increase in interest in crop insurance in Poland. Achieving of the planned level of $70 \%$ of crop area being insured should be possible in 5 years.

5) Commercial insurance as the means of protection against plan production risk is not an effective method of coping with farming risk in Poland yet. Insurance may be effective method under the condition of a very high level of state budget support, which limits the risk of both the farmer and the insurance company. This means that the crop insurance system in Poland is an element of public support for agriculture with less and less farmers' participation.

\section{References}

1. Agricultural insurance schemes (2008). The Current Agricultural Risk Management Systems in the EU and Candidate Countries. European Commission.

2. Bedzie wiecej pieniedzy na ubezpieczenia (There Will be More Money for Insurance) (2016). Top Agrar, 10 (October), p. 18.

3. Bujoczek, K. (2017). Ubezpieczenia rolne ze swiatowej perspektywy (Agricultural Insurance from a Global Perspective). Top Agrar, 11 (November), p. 30.

4. Clipici, E., Frant, F. (2013). The Evolution of Agricultural Insurance Market. Lucrari Stiintifice, Seria I, 15(3), pp. 1-8.

5. Farrin, K., Miranda, M., O'Donoghue E. (2016). How Do Time and Money Affect Agricultural Insurance Uptake? A New Approach to Farm Risk Management Analysis. USDA, Economic Research Service. Report 212, Retrieved: https://www.ers.usda.gov/webdocs/publications/74679/60086_err212_errata.pdf?v=

6. Golebiewska, B. (2011). Significance of Connections with the Environment of Agricultural Farms in Poland for Their Production and Economic Situation. Economic Science for Rural Development, 24, pp. 40-49.

7. Golebiewska, B., Golebiewski, J. (2013). Adjustment of Agricultural Production in Poland to Institutional Change and Economic Situation in the Food Market. Conference Proceedings: Ekonomicky Rozvoj a Management Regionu, 1, pp. 142-153.

8. Golebiewski J. (2013). Changes in Competition Trends and Labour Productivity in the Marketing Chain of Foodstuffs. Economic Science for Rural Development, 32, pp. 178-183.

9. GUS (2017). Rocznik Statystyczny Rolnictwa 2016 (Statistical Yearbook of Agriculture 2016). Warszawa: GUS.

10. Hecka, A., Lyskawa, K. (2013). Ubezpieczenia upraw rzepaku od skutkow zlego przezimowania; uwarunkowania srodowiskowe i ekonomiczne (Rape Crop Insurance from the Effects of Winter Kills Conditioned by Environmental and Economic Factors). Zeszyty Naukowe SGGW w Warszawie - Problemy Rolnictwa Swiatowego, 13(28) (1), pp. 24-36.

11. Janc, A. (2016). Wyzwania w funkcjonowaniu ubezpieczen upraw w Polsce w latach 2006-2016 (Challenges in the Functioning of Crop Insurance in Poland in 2006-2016). Presentation at the conference Ubezpieczenia wobec wyzwan XXI wieku, Rydzyna, 16-18 May.

12. Janowicz-Lomott M., Lyskawa K. (2016). Funkcjonowanie dotowanych ubezpieczen upraw w Polsce (The Functioning of Subsidized Crop Insurance in Poland). Wiadomosci Ubezpieczeniowe, 2, pp. 69-72.

13. Janowicz-Lomott, M., Lyskawa, K. (2011). Partnerstwo publiczno-prywatne w ubezpieczeniach rolnych (Public-Private Partnerships in Agrarian Insurance). Prace Naukowe Uniwersytetu Ekonomicznego we Wroclawiu, 183, pp. 166-177.

14. Janowicz-Lomott, M., Lyskawa, K. (2016). Ubezpieczenia rolne (Agricultural Insurance) [in] W. RonkaChmielowiec (Ed.), Ubezpieczenia (Insurance). Warszawa: CH BECK, p. 419.

15. Kaczala, M. (2015). Zawieranie umow ubezpieczen upraw przez gospodarstwa indywidualne (Conclusion of Crop Insurance Contracts by Individual Farmers). [in] M. Kaczala, K. Rojewski (Eds.), Ubezpieczenia produkcji roslinnej w Polsce. Warszawa: Poltext, pp. 129-154. 
16. Klimkowski, C., Rembisz, W. (2014). Kwestie stabilizacji dochodow w rolnictwie (Problems of Income Stabilisation in Agriculture). Roczniki Naukowe Ekonomii Rolnictwa i Rozwoju Obszarow Wiejskich, 101 (4), pp. 85-96.

17. Kolejki po polisy (Queues After the Insurance Policy). Top Agrar, 10 (October), p. 18.

18. Koniec sielanki: czerwony alarm w ubezpieczeniach rolnych (The End of Idyll: A Red Alarm in Agricultural Insurance). Top Agrar, 4 (April), p. 13.

19. Luczak, P. (2016). Paraliz rolnych ubezpieczen (Agricultural Insurance Paralysis). Top Agrar, 11 (November), p. 3.

20. Makki, S., Somwaru, A. (2001). Asymmetric Information in the Market for Yield and Revenue Insurance. Technical Bulletin No. (TB-1892), Washington: USDA, Economic Research Service.

21. Milewska, A., Wicka, A. (2011). Business Insurance in Polish Agriculture-Situation and Development Directions. Economic Science for Rural Development, 24, pp. 237-242.

22. MRiRW (2018). Ubezpieczenia upraw rolnych i zwierzat gospodarskich w 2018 roku (Insurance of Crop Production and Animals in 2018). Online. Retrieved: http://bip.minrol.gov.pl/InformacjeBranzowe/Ubezpieczenia-upraw-rolnych-i-zwierzat-gospodarskich/Ubezpieczenia-upraw-rolnych-i-zwierzatgospodarskich-w-2018-r

23. Nie podnosic dotacji ubezpieczeniowych (Do Not Raise Insurance Subsidies) (2016). Top Agrar, 11 (Nov.), p. 8.

24. O'Donoghue, E. (2016). Risk Management. Washington: USDA, Economic Research Service. Retrieved: https://www.ers.usda.gov/topics/farm-practices-management/risk-management/risk-in-agriculture/

25. OECD (2011). Managing Risk in Agriculture. A Holistic Approach. OECD, pp. 16-195.

26. Pietrzykowski, R., Wicki, L. (2011). Regional Differentiation in Uptaking the CAP Funds on Agrienvironmental Programmes in Poland. Economic Science for Rural Development, 26, pp. 149-162.

27. Plonka, M. (2017). Przyczyny braku zawierania umow obowiazkowego ubezpieczenia upraw rolnych w swietle badan ankietowych producentow rolnych (The Reasons for the Lack of Concluding Contracts for Compulsory Insurance of Agricultural Crops in the Light of the Questionnaire Surveys of Agricultural Producers). Ubezpieczenia w rolnictwie - materialy i studia, 61, pp. 37-52.

28. Sulewski, P., Kloczko-Gajewska, A. (2014). Determinants of Taking out Insurance Against Losses in Agricultural Production in Poland. Roczniki Naukowe Ekonomii Rolnictwa i Rozwoju Obszarow Wiejskich, 101 (4), pp. 127-135.

29. Tornado w ubezpieczeniach rolnych (Tornado in Agricultural Insurance). (2016). Top Agrar, 11 (November), p. 10.

30. Ubezpieczenia beda ale szczegoly nieznane (The Insurance Will be But the Details are Still Unknown). (2017). Top Agrar, 1 (January), p. 20.

31. Ustawa z dnia 7 lipca 2005 r. o doplatach do ubezpieczen upraw rolnych i zwierzat gospodarskich (Act of 7 July 2005 on Subsidies to Insurance of Agricultural Crops and Farm Animals). (Dz. U. 2005 nr 150, poz. 1249).

32. Wicka, A. (2011). Ubezpieczenia gospodarcze w rolnictwie $w$ latach 2004-2010 (Business Insurance in Agriculture in the Years 2004-2010). Roczniki Naukowe Stowarzyszenia Ekonomistow Rolnictwa $i$ Agrobiznesu, 13(1), pp. 435-439.

33. Wicka, A. (ed.) (2014). Czynniki i mozliwosci ograniczania ryzyka w produkcji roslinnej poprzez ubezpieczenia (Factors and Options for Risk Reduction in Crop Production Through Insurance). Wydawnictwo SGGW: Warszawa.

34. Wicki, L. (2010). Efekty upowszechniania postepu biologicznego w produkcji roslinnej (The Effects of the Biological Progress Dissemination in Plant Production). Wydawnictwo SGGW: Warszawa.

35. Wicki, L. (2012). Convergence of Labour Productivity in Agriculture in the European Union. Economic Science for Rural Development, 27, pp. 279-284.

36. Wicki, L., Wicka, A. (2016). Bio-Economy Sector in Poland and Its Importance in the Economy. Economic Science for Rural Development, 41, pp. 219-228. 